\title{
Sarcasm and Taboo in the Moroccan Mediascape after the February 20 Movement
}

\section{Abdelmjid Kettioui}

To cite this article: Abdelmjid Kettioui (2020): Sarcasm and Taboo in the Moroccan Mediascape after the February 20 Movement, Journal of African Cultural Studies, DOI: $10.1080 / 13696815.2019 .1701426$

To link to this article: https://doi.org/10.1080/13696815.2019.1701426

册 Published online: 10 Feb 2020.

Submit your article to this journal $\pi$

Q View related articles $₫$

View Crossmark data 


\title{
Sarcasm and Taboo in the Moroccan Mediascape after the February 20 Movement
}

\author{
Abdelmjid Kettioui \\ L'École Nationale Supérieure d'Arts et Métiers, Moulay Ismail University, Meknes, Morocco
}

\section{ABSTRACT}

This article aims to conceptualize the interplay between sarcasm, scatology and writing in Darija (Moroccan Arabic or Al-Maghribia) on the web in a post-uprising era. It focuses on the new Darijophone prose that emerged after 20 February 2011 protests in Goud and The New زيليكر (The New Bumpkin). Originating with absurdist February 20 movement founder member, Mohammed Sokrat, this writing genre is realist, vulgar, profane, taboo-breaking, and borrows from the toilet space to poke fun at the schizophrenia, herd mentality and populism that attend a modernizing society under a neoliberal regime. A vocabulary of trash, waste, filthy social types and risqué gags has informed a unique online minoritarian prose that is unpopular, yet widely read. This article studies the virtual politics and poetics of dirt and laughter in written Darija. Writing at the interstices of commitment and co-optation, this subcultural mode of knowledge production reveals Moroccan youth's heretofore suppressed yet incessant longing for change in a post-uprising context of disillusionment.

$$
\text { السخريةه والمحرم في الفضاء الاعلامي المغزبي بعد حركة } 20 \text { فبرايز }
$$

تهدف هذه الدر اسة إلى وضع تصور للتفاعل بين السخرية و السكاطولوجيا و الكتابة بالدارجة

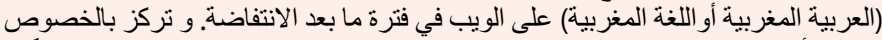

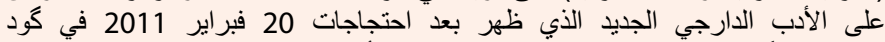

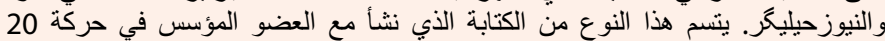

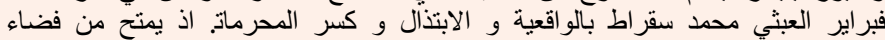

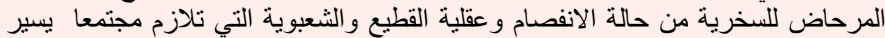

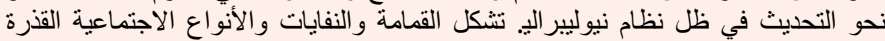

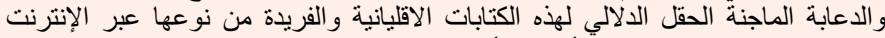

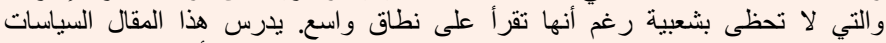

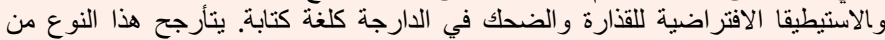

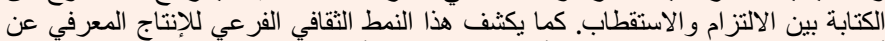

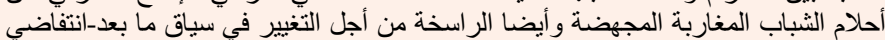
يتسم بخيبة الأمل.

\section{KEYWORDS}

Dirt; Darija; February-20;

Goud; sarcasm; scatology;

taboo; The New

$$
\begin{aligned}
& \text { الكلمات المفاتتح } \\
& \text { الكلمات المفاتيح: القذارة; الدارجة; } \\
& \text { حركة } 20 \text { فبر اير; كود; السخرية; } \\
& \text { سكاطولوجيا; المحرم; النيوزحيليكر }
\end{aligned}
$$

This article provides an in-depth analysis of the aesthetics of abjection, agency, resistance and marginality that haunts the online Darija prose written post-February 20 (F20). It is inspired by Moulay Driss El Maarouf's $(2015,2016)$ concepts of 'excrementality' and the 'poopular' in his work on the encroachment of the abject and scornful laughter in 
Moroccan urban music festival spaces. I aim in this article to offer a new perspective on North African language politics and cultural studies by addressing the gap in the scholarly literature on the politics and aesthetics of writing in Darija in post-2011 Morocco. While a large body of scholarly publications has addressed the transition of Darija into a written language since the 2000s (Miller 2017, 91), post-2011 written Darija on the web has hitherto received little critical attention. Most of the scholarship on written Darija (Alami 2013; Elinson 2013; Miller 2017) centers on the print texts by intellectual elites and already established poets, novelists, translators, journalists, editors and publishers. Despite their status as founding texts in a burgeoning Darijophone literature, these texts are far less known and read compared to publishing in Goud, the writing of which has become a rite of passage for new Darijaphone voices. To reach a larger readership, in January 2016 Darija activist, author, translator and critic Mourad Alami started to republish Arraheel: Dam'aa Msafra, Out (Leaving: A Traveling Tear, 2012), ${ }^{1}$ his 213 -page print novel in serialized episodes in Goud.

Writing a few months before Sokrat's prison diaries broke new ground in a hitherto little known print Darija literature, the outspoken advocate for the constitutionalization of Darija Alami (1 July 2013) identifies three schools of written Darija: the 'traditional school' represented by early and modern zajal (poetry in Darija) writers such as Driss Mesnaoui, the 'Western school' developed by a francophone elite including journalist Driss Ksikes, entrepreneur Noureddine Ayouch and linguist Dominique Caubet, and the 'modernist school' which is a synthesis of both schools and which has an independent, civil society background. Lacking in this analysis is the F20 factor in the evolution of Darija into a written language. It is inevitable to appeal to periodization to account for the more popular Darija literature spawned by F20 and pioneered by Mohammed Sokrat. Attending to periodization, Caubet $(2017,118)$ rightly situates the origins of this writing in the artistic Nayda movement of the previous decade ushered in the relatively open climate of freedom during the early years of Mohammed Vl's reign. Focusing on the Darija of rap music, Caubet (2017) only cursorily highlights writings by El Haqed, Sokrat and other slammers. Hence my intent to give a more nuanced account of the aesthetics of this post-uprising media and literary strand.

In Morocco's 2011 revised constitution, Darija was neither constitutionalized like Tamazight, nor recognized as a component of Moroccan culture like Hassania, a dialect spoken in Southern Morocco. Darija has been the lingua franca of Moroccans for centuries. With influences from French and Spanish, Darija is the hybrid outcome of the interaction between Tamazight, the language of Imazighen, otherwise known as Berbers (Morocco's indigenous communities) and Arabic, the language of Arab invaders in the seventh century (Chafik 1999, 8). Arabic had a restricted use in Moroccan social, cultural and political life before French colonialism. Chafik $(1999,13)$ maintains that Darija was 'exclusively the language of writing', and thus 'unspoken outside limited religious and cultural circles.' Chafik notes that 'the spread of the press, the radio and other media and the relative generalization of basic education' in the 1930s were crucial factors for the spread of Arabic from its primary religious sphere into the 'political, social and cultural' spheres (1999, 13). Since then, pan-Arab ideology has promoted Ummist Islam and Arabization in nationalist struggles for independence across the region.

Sixty years of Arabization proved ineffective especially in education. Today, Darija advocates identify Standard Arabic as a dead language and call for severing ties with an 
imagined Arab Ummah (Alami 2013; Sokrat 2016b; Zaid 2017; Agnouche 2018a; El Baroudi 2018). The inclusion of a few popular Moroccan food names in Darija in textbooks in 2018 sparked a great deal of controversy. While Darija enthusiasts praised this move, pan-Arabists considered it a vulgar onslaught on the language of the Qur'an. Moroccan historian and philosopher Abdellah Laroui (2M 2013) dismisses the mobilization for Darija as 'superficial' since

the aim of focusing on mother tongues and orality in Africa and elsewhere is that you create a class of people who can easily read, people who are not illiterate but who are unlettered. That is, they have limited concepts, so they work only in factories.

This exclusionist dimension of the Darija project contradicts Mourad Alami's (2013) hopeful vision that 'Darija alone can guarantee democracy, equal opportunities and real welfare' because 'through a living language, we employ all the energies and human capital.' Nouhad Fathi (Goud 2018) asserts that the rejection of teaching Darija shows that Moroccans hate their mother tongue. They consider it 'the language of the toilet and bouzebal (lowly social types).' Fearing that the teaching of Darija will only exclude their children from a market economy based on French and, increasingly, English (Miller 2017, 109), a villager mother seen on the sensationalist news website Chouf TV counters Fathi's inferiority complex narrative and Alami's optimistic view in purely economic terms. She (Chouftv 2018) concedes to the camera that Darija would rather be taught to upper-class children who do not know these foods. The mother protests that the wealthy officials 'teach their own children English, French and all the languages and they come to the children of the poor and make fun of us with food names our children know too well.' Echoing Laroui's argument, this illiterate woman gives a perceptively unsettling, class-sensitive account of a hegemonic project which aims to 'dull wlad cha'b (the disenfranchised class) all the more.'

Literature in Darija falls within three distinct strands. The first harks back to ancient folktales and oral music traditions found in the sung poems of zajal, Malhun, Aita, Gnawa, etc. The second spans the first decade of the 21 st century, which saw a veritable explosion in urban youth music festivals and music productions in Darija. The little known Khbar Bladna (News of Our Land) appeared in print in Tangier. It was published by Elena Prentice on 14 February 2002 and was sold in a number of Moroccan cities for more than four years (Elinson 2013, 718). Nichane (Straight Up, 2006-2010), francophone weekly TelQuel's Arabo-Darijophone sister publication which featured uncensored headlines and editorials addressing the king, Islam and sexuality in Darija, was a landmark project that closed after a series of legal trials, and due to its exclusion from state advertisement funding just a few months before Bouazizi's act of self-immolation threw the whole region into the vortex of social and political unrest and incessant cycle of regime change to date. Francophone writer Youssouf Amine Elalamy's Tqarqib Nab (Gossip, 2006), a collection of funny sketches of ordinary Moroccans, is a symbolic contribution. This period has been pivotal for the evolution of Darija into its current form. The third cluster of Darija writings starts with the 2011 uprisings, especially with Sokrat's prison memories in Darija in 2013. Written Darija reached its momentum as young talents and professional writers in other languages started to contribute opinion pieces and memoirs in serialized episodes in Darija to Goud and The New زيليكر.

It is this last strand of literary productions in Darija that this article takes as a case study. In a postcolonial linguistic context dominated by an elite consisting of Arabophones and 
francophones, these gifted young writers have managed to carve out a third space through and for Darija since 2011. Rejecting the top-down assimilation of Darija for commercial and political ends, ${ }^{2}$ these young sarcasts are the engineers of a linguistic transition from below. The controversy around language is not a linguistic one per se. More broadly, it is an expression of a youth subculture reconstructing its postcolonial subjectivity at the interstices of tradition and modernity. These authors in Darija deploy autoethnography to sketch everyday social, political and economic violence, miseries, ironies and subtleties haunting an increasingly neoliberal and globalized postcolony.

Within Morocco's ongoing 'culture wars' between populist Islamists and leftist liberals, a large part of these vulgarizers of high culture and movers of social norms emerge as nihilists and rebels who champion realpolitik against political correctness, 'an enlightened autocrat' against the 'democracy of the herds' and a neoliberal Makhzen over political Islamists. Reversing Bakhtin's (1984) theory of carnival laughter, these sarcasts parody commoners in the first place because they believe the bottom is more threatening to individual freedoms than an increasingly lenient modernist Makhzen. These bloggers' critique of the Makhzen comes in the form of post-irony, thus blurring the line between reality and fiction. Indeed, experiencing imprisonment following the disjuncture of F20, Sokrat among other youths have realized the absurdity of openly countering a mighty 'hybrid regime' (Desrues 2013). ${ }^{3}$ Therefore, sarcasm in Darija looms large as a strategic and subtle line of attack to tease out both the political taboo and the social norms of the 'unwashed masses.' These fun writings emerge in my analysis as political statements that engage a hierarchy of taboo subjects that include topics as diverse as the monarchy, Islam and sex.

\section{Mohammed Sokrat: Co-opted Rebel, Parasitic Writer}

A founder member of the F20, a nihilist and a rebel, Mohammed Sokrat was the originator of this new sarcastic genre as he teased out taboo issues in Darija on the blog he kept since 2006. ${ }^{4}$ The self-taught middle-school drop-out and blogger for individual freedom was among the youth to whom the king-appointed constitution-drafting committee listened (23 April 2011). Sokrat advised that the monarchy should allow female monarchs to ascend to the Moroccan throne. Arrested for allegedly dealing in drugs on 29 May 2012 in Marrakesh, Sokrat was coerced to sign a false confession as his father and brother were illegally detained by police agents. In a video, his mother denounced the arrest and appealed for his freedom. Sokrat's imprisonment was part of the Makhzen's crackdown on Februarists including rapper Mouad El Haqed and poet Younes Benkhdim. F20 and human rights activists campaigned for his release as a political prisoner. After a year and a half in prison, he published his memories in 100 serialized episodes on the Darijophone Goud (22 December 2013 - 30 July 2014). Since then, he has contributed regular opinion pieces to Goud as a freelancer. Having written in Modern Standard Arabic (MSA), Sokrat (21 May 2014, BBC Arabic) chose to publish his prison diaries in Darija because 'the setting where events unfolded, which is prison, entails for communicating a more authentic picture writing in Darija.' Sokrat argues that 'the vulgar exchanges that took place among inmates and prison staff would lose their realism and linguistic vulgarity once translated into MSA.' Goud owner Ahmed Najim (21 May 2014, BBC Arabic) explains that Goud's slogan was 'L'Maghrib bla zwaq (Morocco unembellished), which means addressing 
Moroccans in the language they speak i.e. Darija.' Najim conceded to the BBC that he found in Sokrat's prison diaries' 'unprecedented style at least in Darija' what Goud was looking for, paving the way for other diarists to join the webzine.

Sokrat was a street vendor just like the Tunisian Bouazizi who immolated himself. Unlike Bouazizi, Sokrat was a lover of rock and roll who has read works by Marquis de Sade, Machiavelli, Nietzsche, Bukowski, Beckett, Mounif, Choukri, among others. In a letter to the king (Goud, 5 July 2014b), Sokrat combines sarcasm with post-irony as he begs for royal favors for repenting about his absurd anti-Makhzen struggles in the past. As Sokrat pleads for perks, he exposes and, silently, condemns a deeply-rooted system of royal privileges while addressing the king in a down-to-earth and uncouth Darija, the language of the class he came from. Sokrat, thereby, fulfills the role of what Sartre $(1988,81)$ calls 'a parasite of the governing élite' because 'functionally, he moves in opposition to the interests of those who keep him alive.' Indeed, Sokrat does not fail to denounce social injustice, oppression and the onslaught on individual freedoms. Finding fault with the king's undelivered promises, Sokrat (Goud, 20 August 2015a) contends that 'I no longer believe that change is possible in the way it is happening. I feel hogra (humiliation) and that we are not equal before the law.' The disenchanted former political prisoner longs for the day when

we feel that all of us are Moroccans, not second- or third-degree Moroccans. Then, we will feel that we have a value in this land, and if we vote, our voices will be heard and can change or influence things. While things are the same, isolation and despair for a bright future will prevail.

Sokrat's daring prose had a huge following and inspired a close circle of followers and like-minded misfits including Jawad El Ansari to launch The New زحيليك in 2014, a part-literary, part-news satirical outlet. Siham El Baroudi, who was inspired by Sokrat's writings in Goud, considers him 'the godfather of writing in Darija. His place remains unique like (Jean) Le Pen in the National Front or (Mohamed) Bensaid Ait Idder ${ }^{5}$ in the Unified Socialist (Moroccan Party)' (personal communication, 2018). When, finally, contacted by Le360 news outlet, allegedly owned by Mohamed Mounir El Majidi, the king's personal secretary, and run by Aziz Daki (also the director of Mawazine music festival), Sokrat failed to join the team of journalists. Sokrat (3 October 2015d) was surprised when Daki told him at the job interview that the editorial guidelines of Le360 were different from Goud's as they abide by Morocco's official slogan 'Allah, al-watan, al-malik' (God, Country, King). Sokrat retorted that in Goud they do the same while they add individual freedom and sarcasm to the slogan. Sokrat was told that if he wanted to write an opinion piece, he would have to make a request and wait for approval, a formality he was spared in Goud. Sokrat intimates that

I developed a style uniquely for Goud, which can be published only in Goud. That's because Goud embodies the chaos and freedom of its owner that came to embody our own personalities as people who write for it ... Writing for Goud is ... an addiction like heroine or zoophilia ... I didn't go to Le360 not for the sake of integrity and independence and all that ... but because writing for Goud is a pleasure equal to sex (except sex with Amazonian women which is matchless).

Sokrat's stance vis-á-vis Le360 confirms Jawad El Ansari's claims about the co-optation and dictation common in Moroccan media circles. El Ansari maintains that 
newspaper owners are ready to lower their pants to the ground for the sake of cash. What I like about Najim (owner of Goud) is he lowers his pants only a little bit, not to the extent where he would concede his editorial line. (El Ansari, personal communication, Rabat. 2018)

Besides Sokrat, Hamid Zaid, a philosophy major and poet who studied journalism, contributes opinion pieces in the form of free style poems in a Darija-influenced Fus'ha. Siham El Baroudi who had published for leisure in the The New زحيليكر became a freelancer for Goud. Retired law and political science professor Abdellatif Agnouche published a book serially titled 'How do Moroccan Sultans view themselves and how do they view their Authority and Protect it?' So-called F20 rapper and 'political prisoner' Mouad El Haqed published 'From Okacha (prison) to Molenbeek (Belgium)', his prison diaries in Goud in February 2016. Goud appealed to controversial figures such as LGBT activist Hajar El Moutaouakil, the first Moroccan lesbian ever to tell her story openly in serialized episodes in Goud (10 July -1 October 2016). French language activist journalist Nouhad Fathi, and Ghita Allam, an upper-class sarcastic blogger who married Sokrat (October 2016), joined the cast of contributors with a vengeance.

Pioneers of 'citizen journalism' in Darija, Goud and The New زيليكر published the writings of several gifted outsiders to traditional media. These writers share several common denominators. Mostly born in the 1980s and growing in Hassan II's authoritarian rule, these sarcasts were involved in F20 disjuncture as founder members, protestors, prisoners or mere curious onlookers within a larger 'silent majority.' Most of these urban youth are well-informed bibliophiles and cinephiles who come from middle class families. The young women writers like Fathi and El Baroudi mastered French in public schools and ventured into writing in Darija with a francophone cultural background. For an upper-class woman schooled in French mission schools, Allam experienced cultural shock as she wedded Sokrat and became visible on social media. Sensitive to 'leftist utopianism' and the revival of political Islamism, these authors, much like Plato and Sokrat (Goud, 28 August $2015 b$ ), do not buy into 'the democracy of the raging herds and the inhabitants of the qadous', which represents 'the dictatorship of the majority rabble at the expense of the rational few.' Through a variety of web content ranging from parodies, sarcastic opinion pieces, satirical Facebook postings, memes and trolls, they have established sarcasm in Darija as the lingua franca of the Moroccan web. As such, these authors weaved informal relations of complicity and intertextuality with one another and with a young pubic of avid readers.

\section{What is Philoosophy?}

Philoosophy deals with scatology and laughter and philosophy as the 'discipline that involves creating concepts' (Deleuze and Guattari 1994, 5). I invent philoosophy as a conceptual framework to account for the sarcastic use of the toilet space and its attending colloquialisms and images of defecation, filth, disgust and abjection in the post-2011 Moroccan uprisings. This desublimating and unseemly synthesis of excrement, sarcasm and philosophy is motivated by the proliferation of images of abjection and filth in Morocco's post-2011 uprisings. It is about the creative fooleries of a versatile and hybrid cast of young Moroccan online bloggers, social media unknown-turned-influencer, activist-cum-opinionpiece writers and autobiographers in a hybrid mediascape. Making fun of the bottom and 
what is left of the hybrid F20, its unsung heroes, secularists, Islamists, and romantics, this now pro-regime, now insurgent, anti-intellectualist web intelligentsia of amateurish and talented writers treat uprising and its aftermath in Morocco as a comedy of errors. Against the mainstream media narrative of MENA uprisings as critical events and serious business of political change, a new strand of writings addresses in sarcastic ways the scatological of the social and the political in and after uprising.

The new prose from Goud and The New زحيليك enacts the role of 'a minor literature' (Deleuze and Guattari 1986, 17) in the sense that it 'finds itself positively charged with the role and function of collective, and even revolutionary, enunciation.' Also, this literary current agrees with Asef Bayat's $(2010,90)$ concepts of 'nonmovement' and 'quiet encroachment' to describe 'silent, protracted, and pervasive advancement of ordinary people on the propertied and powerful in a quest for survival and improvement of their live.' The voices of Morocco's post-uprising literature in Darija have silently, diligently and steadily mainstreamed Darija, the language of the 'unwashed masses', into the web's first mode of expression through everyday writing. This minor literature is not the outcrop of professional, salaried pundits. Rather, it is the voluntary work of an intelligentsia from below that has managed to speak to people's everyday concerns. Thus, inventing amateurish and creative counternarratives and, ultimately, counterpublics. 'Minor literature is always socioculturally and politically engaged, and the author who contributes to it never writes in a cloistered room away from the fray' (Orlando 2009, xiii). It is in this sense that philoosophy as a major strand within a burgeoning Darija literature acts on the now towards engraving a future insurgent consciousness. This genre has invented toilet space-inspired vocabulary to set forth, among other things, the ethics and 'aesthetics of vulgarity' (Mbembe 2001, 102), dirt and abjection that surround female and male virtue and agency in a predominantly patriarchal society. The jargon of this prose includes lqadous (gutter), qadousism, qadousist thinking, zbel (trash) and bouzebal.

Taking my cue from George Bataille's $(1962,58)$ emphasis on the 'unmistakable links between excreta, decay and sexuality', this article places the abject and the corporeal at the forefront of taboo and transgression. ${ }^{6}$ The new Darija prose studied here zeroes in on the 'grotesque body' and 'the lower bodily strata' and their attending images of defecation and vulgarity. Unlike Bakhtin's $(1984,11)$ 'carnivalesque' that celebrates 'a continual shifting from top to bottom, from front to rear', philoosophy shows how visionaries from below set out to mock, or otherwise sublimate, the bottom as they push against the taboo. Although these sarcasts abide by the ideologies of the monarchy, they are the authors of a script that subverts the foundations of Moroccan monarchy and pan-Arabism; namely, Standard Arabic as the sacred language of the Qur'an, Islam and, ultimately, an imagined united Ummah. It is therefore misleading to place this writing within a clearly demarcated camp. Even when authors like Sokrat and Zaid are, by their own accounts, assimilated by the Makhzen, their writing emphasizes dirt's subversive potential and scatology's ability to embody threat not as an isolated or external category. Unlike Kristeva's $(1982,71)$ definition of 'excrement and its equivalents' as that which 'stand for the danger to identity that comes from without', philoosophy treats dirt as an integral part of the order of things as it resists eradication and mocks power.

In these texts, dirt does not emanate from instinct as is the case in the colonial travel narratives studied by Stephanie Newell. It rather originates from intellectual deliberation. Hence philoosophy's incongruity with Newell's $(2015,8)$ definition of dirt as a 'failed 
interpretive category.' In a post-F20 context of disillusionment (Belghazi and Moudden 2015), 'disgust ... and laughter' become 'complementary ways of admitting an alterity that otherwise would fall prey to repression' (Menninghaus 2003, 10-11). After F20, fun became fundamental in youth's everyday narratives of disenchantment and hope for change.

\section{Before "the Era of Facebook in Darija:"7}

Nouhad Fathi describes her personal experience of 'urban apartheid' (Abu-Lughod 1980) in postcolonial Casablanca, prior to Morocco's unofficial transition to written Darija. In the 1990s and early 2000s, so argues Fathi,

the dictatorship of French was absolute. If you got into a shop in Maarif (a posh Casablancan district) and wanted to buy a pair of pants, no one would talk to you if you didn't prove you belonged to the bourgeois class by greeting with the word 'bonjour.'

This language-based class discrimination was felt more deeply in the elitist francophone media she worked for:

I personally suffered from this hogra in my early years of service in francophone media. I moved from a popular neighbourhood and a French learned from books to a bourgeois circle that measures you by your first spoken language to send you to interview home maids and car guards because this was the connection they made with Darija. (Goud, 6 September 2018)

Its elitism notwithstanding, TelQuel's activism for Darija was 'unique' in that it brought a wide range of Darija actors especially marginal voices together (Iddins 2015, 12). Darija underwent a paradigm shift in the first decade of the twenty-first century, developing from a language of vulgarity and dirt 'associated with illiteracy, backwardness and considered incompatible with education or progress' into the 'trendy and modern... language of the Nayda' (Caubet 2017, 118). With the proliferation of state-sponsored urban music festivals under royal patronage (Belghazi 2006), Darija became the language of the underground, rap, rock and roll, fusion and heavy metal. In a special issue aptly titled Nayda, Caubet $(2006,44)$ identifies in the new urban artistic scene a 'Morocco that a generation is reinventing through its mother tongue.' Since then, Darija was evolving from Arabizi (Latin script) to the Arabic alphabet and from short mobile texts to full-fledged literary texts (Caubet 2017, 118).

In the early years of Mohammed VI's reign, a wave of critical and independent press emerged within a heretofore predominantly partisan mediascape (Benchenna, Ksikes, and Marchetti 2017, 4-5). Rachid Niny's satiric Darija-tinctured column 'Chouf tchouf' ('who knows') boosted the popularity and sales of Assabah newspaper since 2000, Al Massae (2006) and Al Akhbar (2012) (Benchenna, Ksikes, and Marchetti 2017, 8). Although Nichane included only 10 per cent Darija, it became a top-selling weekly as it addressed youth's concerns and aspirations, and as its covers and editorials ran headlines in uncut streetwise Darija (Elinson 2013, 718). ${ }^{8}$

However, this relative atmosphere of freedom soon gave way to a state crackdown on critical media after the 2003 terrorist attacks in Casablanca. Journalists who transgressed the red lines: King, disputed Western Sahara, Islam and sex risked law suits, jail or heavy 
fines besides boycott by advertisers. Nichane joined TelQuel in directly criticizing the king's policies, and monopoly of power and pushing against social norms. ${ }^{9}$ Following ongoing pressure from the authorities, Nichane closed down permanently in 2010 as the authorities destroyed 100,000 copies of Nichane and TelQuel on 1 August 2009 featuring a public opinion poll where 91 percent of participants expressed favorable views on the first decade of King Mohammed Vl's reign.

Sokrat (Goud, 12 October 2016a) laments the loss of Nichane as

it spoke to us and our aspirations, and we saw it as the beginning of a new era of a Moroccan press that addressed us intelligently, enlightened us, and broke the taboos and the fear instilled in us by the preceding generation who had suffered repression and passed fear and conformist thinking down to us.

When Nichane ended, so maintains Sokrat, 'we became orphans.' For Sokrat, the foreign press was nothing like Nichane which 'had another taste, the taste of a modernist Moroccaness that was in step with the times.'

The spirit of Nichane lived on in Goud (whose tagline read Dima Nichane, or always Nichane), the Darijophone news outlet launched by Ahmed Najim, a former journalist in Nichane, in 2011. Choosing to publish in Darija in the Arabic script, Goud promised to militate against obscurantism and champion universal values of democracy and secularism (Goud, editorial, 2012). ${ }^{10}$ It wasn't until 2013, with the publication of Sokrat's prison diaries in a popular and honest Darija that the online newspaper came to the limelight.

Certainly, Morocco's political class has remained inattentive to the Darija question preand post-2011. It was in rap music, the press industry and social media platforms that Morocco's unofficial transition to Darija steadily took place. The ascent of Abdelilah Benkirane, the eloquent and charismatic then head of Islamist PJD party, ironically gave Darija new momentum as his popular speeches in the Moroccan vernacular within and without the parliament encouraged the use of Darija among Morocco's political class, and politics started to have a following from uninterested youth. The irony lies in the fact that Benkirane and his Islamist party, much like the monarchy, are against recognizing Darija as an official language in Morocco. For Abdellatif Agnouche (Goud, 12 September 2018b), 'Arabic is the basis of the Makhzen's political legitimacy.' Hence, 'the Makhzen cannot allow the use of Darija in formal education because this means cutting off his family line and ... ending the religious legitimacy that put it firm in place.' Agnouche (Facebook, 6 September 2018a) is, however, hopeful that even Darija detractors 'have finally come to realize that Fus'ha is the language of the dominant political and religious classes, and that the mother tongue (Darija) can serve you well in philosophy, the sciences, fiction and literature.'

It is within this politicized Fus'ha-Darija controversy that Sokrat sets out to refute Ayouch's alleged defense of Darija from media campaigns to the publication of the first ever Darija-Darija 1000-page dictionary. ${ }^{11}$ 'When Ayouch was compiling my late grandmother's glossary of Darija', so argues Sokrat (Goud, 16 December 2016c), 'Goud was developing it through daily writing to instill it in the reader's subconsciousness as a language that you can use to write the news, an opinion piece or even knowledge'. For Sokrat, a real dictionary for Darija can only be possible by investing in the youth who have mainstreamed Darija through 'personal means.' Agnouche, too, (Goud, 18 December 2016) dismisses Ayouch's endeavor as nonsense since only the state can 'institutionalize' Darija, calling on the state to create 'an academy for the Moroccan dialect.' 
To cope with this linguistic dilemma, Hamid Zaid has invented what he calls a 'third language' that combines the solemnity of Fus'ha and the vulgarity of Darija. Zaid explains why Fus'ha is dying out in Morocco's metropolitan cities. He (Masharif, 13 December 2017) concedes to the camera that

when I thought about becoming a writer and poet, I wanted to write in a flawed language. I wanted to get close to the Moroccan language and the Moroccan youth. That was my first concern. People who think I am redundant are wrong. I confront Fus'ha and I am scarce in the use of it. I don't use clichés and I handle language on a daily basis. I exclude from it a great deal that others use and wrongly think it's language. That is a ready-made language and there is no creativity and innovation in it and it will lead us to the abyss ... We should've thought about a third language long ago. And we haven't done that. I militate in my own way for this language and I think I have been successful to a certain extent. My readers are like me. They are turned off by fasa'ha, of the claim to fasa'ha (accuracy in Fus'ha). Fus'ha suffers from its users. Classical Arabic is not a solution. It is anti-creativity in language. No matter how you stick to it, you are only damaging it.

To be sure, the proliferation of toilet-space sarcasm is intertwined with the rise of Darija. This occasion of emancipation of the tongues made coping with taboo in politics, sexuality and religion inevitable, if not fashionable. The toilet and its attending images of excrement and filth have witnessed a discursive paradigm shift on the web. From the euphemism of mirhad, its name in Fus'ha, twalet, its equivalent in Darija, no longer caused any embarrassment whatsoever. Ranging as it does from the talk of the political class, religious clerics, marginal social types to social media commentators, shit has reigned rampant on the Moroccan web post-F20 uprisings.

In late August 2011, politicians from competing political parties besides academic and Islamist movements specialist Mohammed Darif gathered at L'Institut des hautes études de management (HEM) in Casablanca to debate the scenarios of the upcoming legislative elections. The then head of the Justice and Development Party Abdelilah Benkirane took issue with Darif's criticism, asserting that 'andi lhaq nrod' (I have the right to answer back). Capturing the polysemy in the Darija verb 'nrod', which means both reply and vomit, Darif retorted before a public of students: 'ila bghiti trod, sir I twalet' (if you want to puke, go to the toilet). Defining the would-be prime minister's talk as vomit, Darif's comment caused a burst of laughter and the withdrawal of the then labor minister Jamal Aghmani for the inappropriate twist the debate was taking. In another video footage that went viral in September 2013, Mohamed el Ouafa, then minister of national education, asked a headteacher on a live videocall if there was a toilet in his school and if it worked. El Ouafa received praise for his frankness and blame for his trashiness on social media platforms.

\section{When was Shit in the Moroccan Mediascape? Déja-Poo, Since the Lead Years}

The interplay of dirt and social protest is not without precedent in Morocco's postcolonial political life. In Morocco's oppressive 'Lead Years', the late Hassan II defined in a televised impromptu speech in Darija in 1984 the protest leaders in Nador, Al-Hoceima, Tetuoan, Ksar El-Kebir and Marrakech uprisings as aoubach or social trash. In this royal speech timely posted on YouTube after the F20 protests, Hassan II asks if Moroccans have lost all manner of sense. He defines the aoubach as 
those unemployed who live on contraband and plunder. In Marrakech, as is the case with troublemakers, protesters put children at the front in demonstrations. I am telling you that the ouebach were put away...I am telling young people and students that it is for their sake that the cost of living has gone up. I am telling these young protesters not to fool with us. They will be subject to the same laws as other troublemakers. ${ }^{12}$

The regime's 'necropolitical' (Mbembe 2003) understanding of dissent defined protestors as a disposable population hailing from a vulnerable social class and, what the French colonists had dubbed, 'useless Morocco.'13 Indeed, political opponents were left to rot in the infamous one-time Tazmamart prison facility. Certainly, the term aoubach shaped collective memory of the state's representation of its grassroots protest movements. This linkage between protest, social class and trash was pronounced in the hirak that ignited the Rif region (in late October 2016) after a fishmonger was crushed inside a garbage truck, as police officers allegedly ordered the driver to 't'han mmou' (grind his mum) i.e. literally grind the journeyman who jumped inside the truck to recover his presumably unjustly confiscated merchandise. Whether actual or made-up, 't'han mmou' was felt by the inhabitants of a region long hostile to the regime as the enactment of Hassan II's designation of Riffians as aoubach. By means of what Gayatri Spivak calls 'strategic essentialism', ${ }^{14}$ pro-hirak activists online and on the streets chanted 'we are all aoubach' and 'tahnouna kamlin' (smash us all). And to speak back to a historical misrepresentation, protestors also shouted 'nass rif machi aoubach' (people of the Rif are not aoubach). ${ }^{15}$

Excrement looms large as an effective resistance strategy in Sokrat's writings. In one of his prison memories, Sokrat (Goud, 10 February 2014a) describes an instance of what El Maarouf $(2015,2)$ calls 'excrementality', 'an instance of tactic acknowledgement of tabouzbalit (the state of being a remainder) as an intrinsic trait, and employment of this essentialism as a strategy to put up resistance.' Sokrat saw an inmate 'half of his body dipped in shit including his face' running after the prison warden, wishing to embrace him.

The prison staff were trying to detain him, but they could not get hold of him, until some people enveloped him in blankets and caught him. When they stopped him all the inmates had already broken into loud laughter. I laughed out loud until tears welled up to my eyes. I asked who the person was and was told it was Mustapha Mjiriba.

Sokrat (10 February 2014a) maintains that

Mjiriba is a real prisoner. I have never imagined a dirtier form of protest. It was so efficient and Mjiriba managed to get his message through. More importantly, it sent the representative of power running away scared and fearing that he might catch shit.

This episode denotes 'the marginal type's awareness of his/her significance as a discardable element' (El Maarouf 2015, 4). Sokrat recognizes in Mjiriba's performance of excrementality a tactic of effecting popular political change. While seemingly subjecting protesters to the same dirtying discourse developed by Hassan II, Sokrat, as a 'parasitic writer', mobilizes them to pay back the representatives of state power. He (10 February 2014a) sarcastically links the protesters' failure to effect change to their lack of a clearly defined excremental strategy. Sokrat thought that F20 activists should have experienced prison before doing the revolution. He 'imagined them tarnished in shit and chasing the policemen away. I imagined the latter running away afraid that they might be immersed in shit.' Sokrat also 
imagined the unemployed youth doing the same and running after policemen in front of the parliament building and everyone can smell the stink from Bab El-Hed. It would have been a scene of filth, but one that is very expressive and efficient. And like Mjiriba who prevailed against oppression, these protesters' demands would have been answered had they followed the same tactic. They would have instated a parliamentary monarchy and a popular democratic constitution. Although this would be achieved with a stinking atmosphere, it would be worthwhile.

As Sokrat outlines the F20 movement's flaws, he espouses an excrementalization of protest. Sokrat (Goud, 10 April 2015c) shows that shit coming from politicians is unpleasant and unbearable. Reading the populist twist in the Moroccan political scene post- the 2011 MENA uprisings, he pits the margin's excrementality against the 'bottom mentality' of the nouveau riche politician.

The pit is bottomless just like the populism of our political leaders. While they give you hope in the Moroccan political scene in the sense that you can hail from the bottom and go up the echelons of politics, the problem is when you carry with you the whole bottom to the top and the summit has no influence on you, but you stick to your bottom mentality.

Teasing the then head of the al-Istiqlal political party Hamid Chabat's dirty politics of insulting his political rivals, Sokrat maintains that 'because Chabat came from the bottom, he still practices politics with a bottom mentality.'

\section{The New زيليكان : The Lowly through 'the Eye and Astonishment of the Elitist $^{16}$}

The bottom is placed at the forefront of the elitist through dark humor in The New زيليكر. The anti-intellectualist webzine (operative between 9 September 2014 and 4 September 2016 and with a following of 60,222) featured literary and sarcastic content in Darija to poke fun at the absurdities of Moroccan political, social and cultural life. The New زيليكر was an open platform for everybody to express their views and tell stories, especially those with sarcastic overtones. It closed because of 'the lack of funding from advertisers and sponsors.' Co-founder Jawad El Ansari maintains (personal communication, Rabat, 2018) that 'we needed funding, but it was also an obstacle as it restricts you.' The New زحيليك represented to its founders 'something like a soccer squad practicing in the amateurish division of the Darija championship' (El Ansari, El Baroudi, personal communications, 2018) that furnished Goud, 'a premier league club', with several gifted authors. Interestingly, The New Yorker-inspired literary outlet's slogan reads 'it doesn't matter if you are a nonentity. What matters is what you say' (The New, زحيليكر 2014).

The magazine title itself embodies this collapse between low and high culture. It is derived from The New Yorker

which has been successful due to promoting a certain intellectual model characterized by a simple and dry language as well as a sharp sense of sarcasm. For its symbolism as a foreign industry i.e. an unquestionably high cultural product, we saw that the title combines the 'elitist' and the 'lowly'. (The New jحيليكر;, 2014)

Likewise, The New زيليكر is a celebration of Zhiliga (the second part of the title), a marginal Moroccan town in the suburbs of Casablanca. Zhiliga is used to connote people's unrefined tastes. 


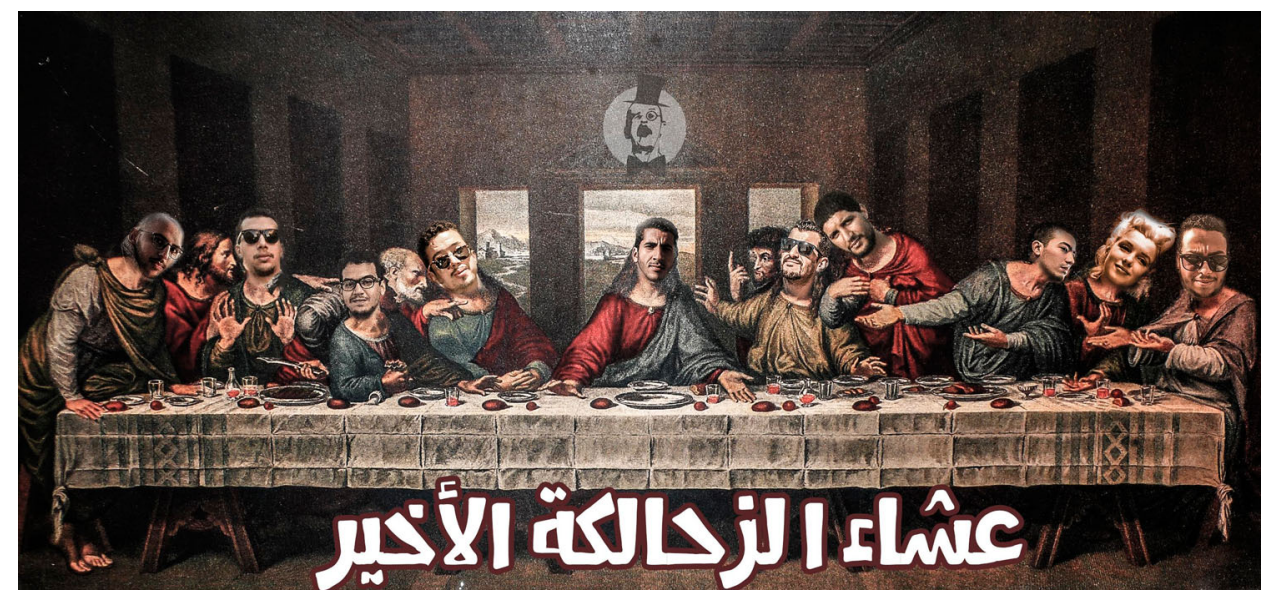

Figure 1. A'zahaliga's last supper, a parody of Leonardo da Vinci's 15th-century mural painting (courtesy of Naoufal Chaara, The New زحيلكر).

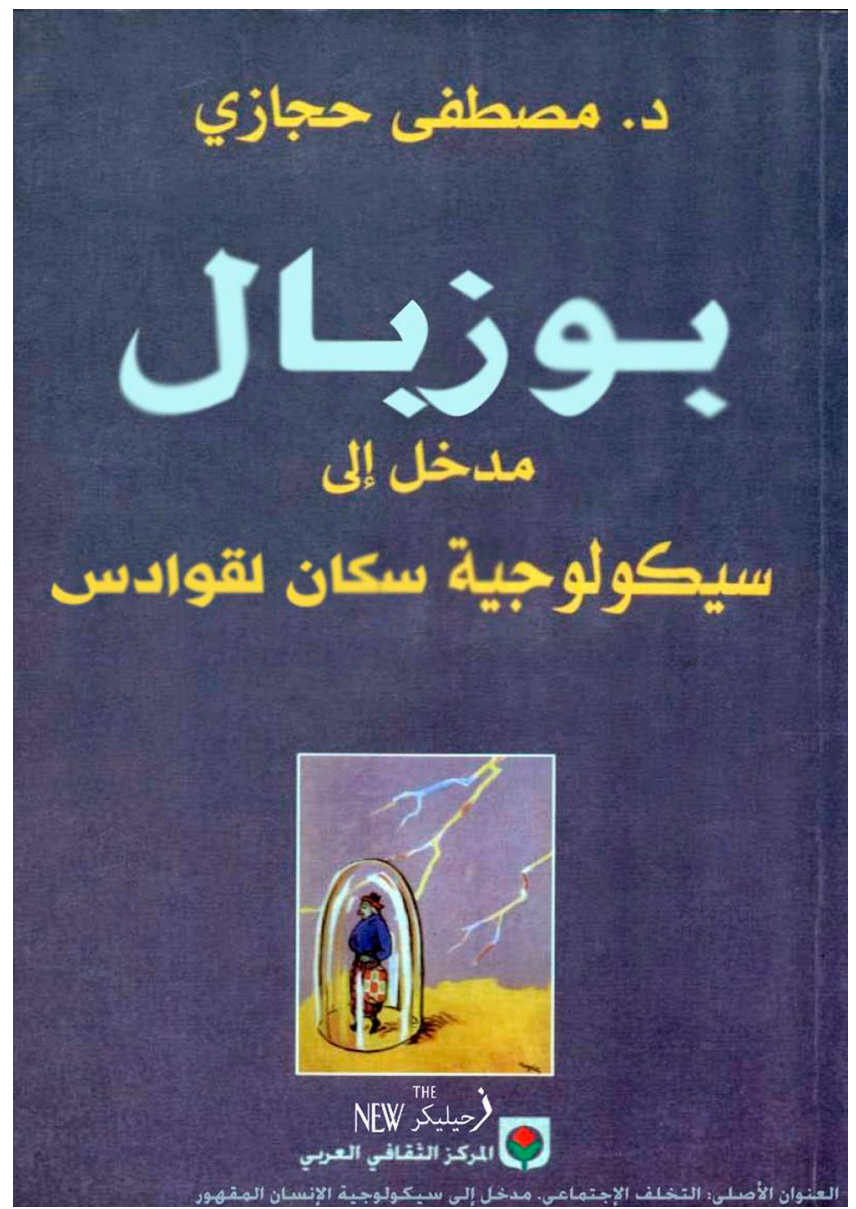

Figure 2. A parody of Hijazi's Attakhalof Al- ljtimai. 


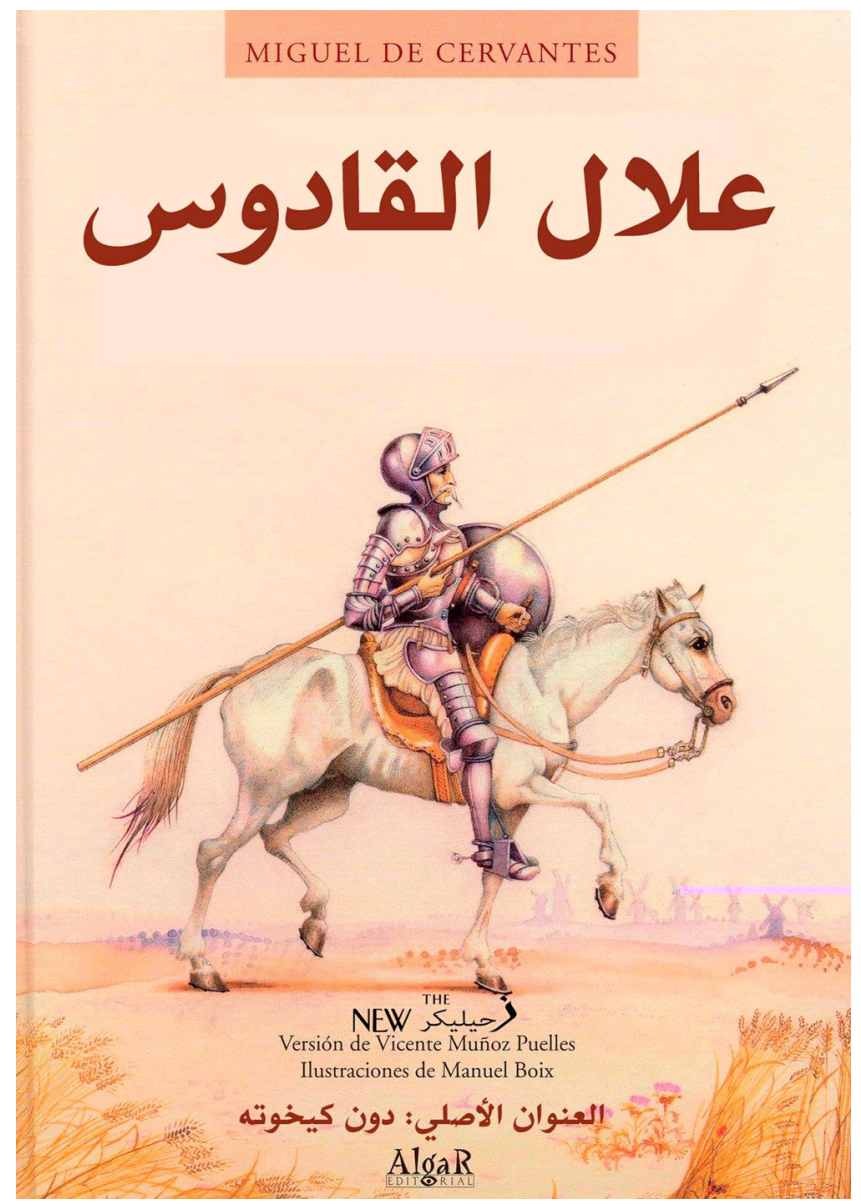

Figure 3. A parody of Cervantes's Don Quixote.

It stands for the culture that everyone is distancing themselves from and everything that can refer to the margin just like Zhiliga, the town. Worse, many things which we should be proud of as our greatest Moroccan cultural products in their raw state are framed as low art, which many of us probably consume secretly and do not brag about in the same way a consumer of a culture branded as a sophisticated product does, although it is not meant for us or we can't understand it. (The New حيليكر;, 2014)

The magazine's logo is an instance of sublimation of a marginal and lowly figure. The New زيليكر's logo represents this mix of low and high culture as it presents El-Kraimi, a popular humorist mostly active in rural marketplaces as an urban, professional comedian with a hat and bowtie (Figure 1).

Figure one frames the progenitors of this sarcasm prose in Darija like Sokrat, al-Ansari, El Baroudi and others as Zahaliga. Here as in their writings, these sarcasts parody the staged intellectualism of millennials and the old guard. These intelligent observers and interpreters of everyday life in Darija regale in amateurism and anti-intellectualism. The readers' section of the webzine summarizes world classics 'from a purely Moroccan popular viewpoint' by wittily retitling book covers in Darija. According to Walter Benjamin 
$(2019,173)$, to 'reproduce' a 'work of art', as these memes do, is 'to destroy its aura', creating, through elements of dirt and the vernacular, a new aesthetics of appreciation as showcased in Figures 2 and 3.

The parodic retitling of these book covers fulfills the webzine's mission of collapsing 'high culture' onto 'a margin beneath low culture' and 'representing elitist content in Zhiligan codes.' Figure 2 is a reworking of Mustapha Hijazi's Attakhaluf Al ljtimaii: Madkhal ila saykoloujiat al-isan al-maqhour (Societal Underdevelopment: An Entry into the Psychology of the Oppressed) into Bouzebal: Madkhal Ila Saykoloujiat Sukkan Lqwadas (Bouzebal: An Entry into the Psychology of Gutter Dwellers). Mustapha Semlali, the simpleton-hero who spared the inhabitants of Rabat's unprivileged al-Massira neighborhood in Yacoub El Mansour District inundation in 2014 as he dived into and cleared the blocked gutters, earned web users' sympathy and the title of Allal lqadous (the gutter's hero). Allal Lqadous replaces Don Quixote in Figure 3 to depict the heroization of a human discard, subjecting Don Quixote to a sarcastic cultural translation in the postcolony.

\section{Conclusion}

The circulation of images and narratives of waste in the Moroccan vernacular has dominated the Moroccan web after the F20 movement. This toilet-inspired sarcasm genre places the taboo at the heart of disgust and laughter. Hence, philoosophy serves as a critical problematization of the premises and promises of a desublimating prose narrative. These Moroccan web sarcasts are intelligent, realist, carefree, enterprising, vulgar, often shocking, unapologetic and, incessantly, quarrelsome. Their writings in Darija unmask the ironies of social life in Morocco in detailed and, oftentimes, autoethnographic portraitures and caricatures. The writings of Sokrat, Zaid, El Baroudi, Fathi, El Ansari and others are indices of a radical, urban post-uprising consciousness operating against the hegemony of accepted norms, MSA and French, populism, schizophrenia and the herd mentality of the masses.

The unpopularity of this genre among the more conservative section of Moroccan society comes from its elitism, interstitial position between commitment and co-optation, parasitism (Sartre 1988, 81) and Platonic mistrust of the bottom. This notwithstanding, this new Darija strand is revolutionary not in the sense of mobilizing people against the state, but in the sense of carving out a new literacy, literality, sensitivity and a counter-public. This media and literary current has drawn a large readership as it speaks to young people's personal and everyday concerns. Also, this new sarcasm-based Darija prose disorients the long-standing belief that Darija is unfit for sophisticated, sublimated literary and philosophical expression. Darijophones today transgress taboo in religion, politics and sexuality by appealing to scatology. Therefore, the story of this literary movement in Darija is also about how the enlightened bottom, albeit co-optation, can serve as an alternative emancipatory force to an elite of intellectuals and politicians far removed from Moroccan socio-cultural realities and dynamics of change.

Hassan II's clampdown on philosophy in the 1970s (Sater 2010, 58) has had indelible unsavory consequences on Morocco's socio-cultural consciousness. What this new prose has revealed in the face of extremism and schizophrenia is the need for philosophy. And 'the need for philosophy here and now', as Mohammed N. Affaya (2014, 124) argues, 'is the need for enlightenment, emancipation from factors of backwardness, 
speaking truth and not fearing freedom. It also means disposing of the metaphysics of the text and attending to the transitions in discourses and realities.' The state's clampdown on hirakists in the Rif and Jrada, critical journalists and individual freedoms has shown that the bottom is neither irrevocably conformist nor the state inherently modernist. Hence the need for revisiting the bottom and the elite as volatile interpretive categories for a more ethical attitude on the part of this intelligentsia of Darija writers. Certainly, it is high time we employed ourselves in tracing the fun and shit politics that has informed minor narratives of enlightenment in Darija on the Moroccan web. Our need for what I call 'a brown cultural studies' (BCS) to study the invention, appropriation, circulation and reception of scatological aesthetics is inevitable.

\section{Notes}

1. Unless otherwise stated, all translations are mine.

2. The Darija-Darija dictionary compiled by Ayouch, advertiser, entrepreneur and close friend to the king, was slighted by these authors and the large public as a pointless endeavor.

3. Unlike Sokrat, imprisonment did not discourage El Haqed from keeping the same hard-line attitude regarding the monarchy and the police. The young rapper who was imprisoned three times released a clip klab dawla (or the state's dogs) to address police corruption.

4. Sokrat, Mohammed's real family name, is the Arabic equivalent of Socrates. See his blog at: http://mohammedsokrat.blogspot.com

5. These two figures are iconic. Le Pen funded the right-wing populist and nationalist National Front political party in France in 1972 and presided over it until 2011. Bensaid Ait Idder founded the Unified Socialist Left party in 2002.

6. Bataille argues (57) that

the horror we feel at the thought of a corpse is akin to the feeling we have at human excreta. What makes this association more compelling is our similar disgust at aspects of sensuality we call obscene. The sexual channels are also the body's sewer.

7. El Baroudi. Facebook interview, 2018.

8. In an editorial titled 'Derrej a Khouya' (Speak Darija, bro), Benchemsi asks the king to speak Darija.

9. The magazine's frontpage headlines read: 'sidna ach tatgoul?' (my sir, what do you say?), 'elbakkara zayad naqass?' (virginity: not a requirement?), etc. Nichane was censored in 2006 after publishing an issue on 'ennokat: Kifach lemgharba kaydahkou a'la din wal jins wa siyasa?' (Jokes: How do Moroccans laugh at religion, sex and politics?). (Benchemsi 2006).

10. Goud grew more unpopular as it demonized the anonymous online boycott movement against Afriquia Gas stations owned by Aziz Akhannouch, billionaire minister of agriculture and fisheries and president of a royalist political party, Sidi Ali bottled water, and Frenchowned dairy products Centrale Danone on 20 April 2018.

11. Ayouch appeared in a face-to-face debate about Darija with Abdellah Laroui on public television 2M on 29 November 2013. Laroui was against writing in Darija because it would stop nonMoroccan Arabic-speakers from understanding texts in Darija.

12. Hassan II, 1984, https://www.youtube.com/watch?v=INHR7Zh5QR4

13. The French colonial administration divided the country into 'useful Morocco' and 'useless Morocco.' After independence, the monarchy continued to view Morocco within this division.

14. Gyatri C. Spivak (1993, 3-4) here means that racially and other marginalized groups seek empowerment through momentarily adopting the very marginalized positions they are reduced to by dominant forces.

15. The protests in Al-Hoceima ended up with sentencing leading hirakists like Nasser Zafzafi up to 20 years in prison.

16. Editorial, The New, 2014. 


\section{Acknowledgements}

The author thanks the editor and anonymous reviewers for their valuable comments. He also thanks Amir Hamid, M. Driss El Maarouf and Jamie Woitynk for commenting on an earlier draft of this article.

\section{Disclosure statement}

No potential conflict of interest was reported by the author.

\section{Funding}

This work was supported by DAAD: [Research fellowship].

\section{ORCID}

Abdelmjid Kettioui (D) http://orcid.org/0000-0002-3227-7384

\section{References}

Abu-Lughod, Janet L. 1980. Rabat: Urban Apartheid in Morocco. Princeton: Princeton University Press. Affaya, Mohammed Nour el-Din. 2014. Fi Annaqd al-Falsafi al-Moaasir: Masadiroho al-Gharbia wa Tajaliyatoho al-Arabia (Critique in Contemporary Philosophy: The Western Origins and the Arabic Manifestations). Lebanon: Markaz Dirasat al-Wahda al-Arabia.

Agnouche, Abdellatif. 2016. "Darija and Ayouch's Nonsense." December 18. https://www.goud. الدارجة-وتخربيق- عيوش - ma/258026

Agnouche, Abdellatif. 2018a. "Arabic is the Legitimate Weapon of the State, Islamists and their Minions." https://www.facebook.com/permalink.php?story_fbid=729020774108606\&id=1000100 20692277.

Agnouche, Abdellatif. 2018b. "Calm Down. The Makhzen will Never Abandon Arabic." https://www. goud.ma/381875-غير-تهناو -ما-عمر -المخزن-يتخلى-على-اللغة/21/.

"Akhbar ... bil 'Ammia." BBC Arabic online. May 21 2014. https://www.bbc.com/arabic/tvandradio/ 2014/05/140521_slang_arabic.

Alami, Mourad. 2013. "Tarsim A'lugha al-Maghribia- Tamghrabiya." https://www.yabiladi.ma/articles/

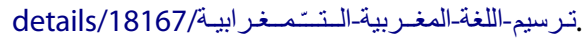

Bakhtin, Mikhail. 1984. Rabelais and His World. Translated by Hélène Iswolsky. 2nd ed. Cambridge: MIT Press. [1st ed. Bloomington: Indiana University Press, (1973)].

Bataille, George. 1962. Death and Sensuality: A Study of Eroticism and the Taboo. New York: Walker and Company.

Bayat, Asef. 2010. Life as Politics: How Ordinary People Change the Middle East. Amsterdam: Amsterdam University Press.

Belghazi, Taieb. 2006. "Festivalization of Urban Space in Morocco." Critique: Critical Middle Eastern Studies 15 (1): 97-107. doi:10.1080/10669920500515168.

Belghazi, Taieb, and Abdelhay Moudden. 2015. "Ihbat: Disillusionment and the Arab Spring in Morocco." Journal of North African Studies 21 (1): 37-49. doi:10.1080/13629387.2015.1084097.

Benchemsi, Ahmed Reda. 2006. "ennokat: Kifach Lemgharba kaydahko 'ala din; ljins, siyasa." Nichane.

Benchenna, Abdelfattah, Driss Ksikes, and Dominique Marchetti. 2017. "The Media in Morocco: A Highly Political Economy, the Case of the Paper and On-Line Press Since the Early 1990s." Journal of North African Studies, 1-25. doi:10.1080/13629387.2017.1307906.

Benjamin, Walter. 2019. "The Work of Art in the Age of Mechanical Reproduction." In Illuminations, edited and introduced by Hannah Arendt, translated by Harry Zohn, 166-195. New York: Mariner Books.

Caubet, Dominique. 2006. "Génération Darija!." TelQuel 229: 44-47. 
Caubet, Dominique. 2017. "Morocco: An Informal Passage to Literacy in dārija (Moroccan Arabic)." In The Politics of Written Language in the Arab World: Writing Change, edited by Jacob Høigilt, and Gunvor Mejdell, 116-141. Leiden: Brill.

Chafik, Mohamed. 1999. Darija al-Maghribia Majalo Tawarod bayna al-Amazighia wal Arabia (The Moroccan Dialect: A Field of Confluence Between Amazigh and Arabic). Rabat: Moroccan Academy Press.

Chouftv. 2018. "A Funny Comment by a Villager Mother Following the Controversy of Including Darija in Some Textbooks." September 8. https://www.youtube.com/watch?v=Q_KGmbJycM.

Deleuze, Gilles, and Félix Guattari. 1986. Kafka: Toward a Minor Literature. Minneapolis: Minnesota UP.

Deleuze, Gilles, and Félix Guattari. 1994. What is Philosophy? Translated by Graham Burchell, and Hugh Tomlinson. London: Verso.

Desrues, Thierry. 2013. "Mobilizations in a Hybrid Regime: The 20th February Movement and the Moroccan Regime." Current Sociology 61: 409-423.

El Baroudi, Siham. 2018. "What Will Happen if Our Schools Shift to English Instead of Arabic, Like the Indians?" https://www.goud.ma/340584-شنو-غادي-يوقع-كاع-لا-بدلنا-لغة_التنريس/.

Elinson, Alexander E. 2013. "Darija and Changing Writing Practices in Morocco." International Journal of Middle East Studies 45 (4): 715-730.

El Maarouf, Moulay Driss. 2015. "The Aesthetic and Practical Fields of Excrementality of L'boulevard Festival." Social Dynamics: A Journal of African Studies 40: 575-588.

El Maarouf, Moulay Driss. 2016. "Po(o)Pular Culture: Measuring the Shit in Moroccan Music Festivals." Journal of African Cultural Studies 28 (3): 327-342.

Fathi, Nouhad. 2018. "All this Fuss about Darija is Because We Hate Ourselves." September 6. https://

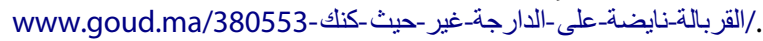

Iddins, Annemarie. 2015. "Debating Darija: Telquel and Language Politics in Modern Morocco." Media, Culture \& Society 37 (2): 1-14. doi:10.1177/0163443714560133.

Kristeva, Julia. 1982. Powers of Horror: An Essay on Abjection. Translated by L. S. Roudiez. New York: Columbia University Press.

Mbembe, Achille. 2001. On the Postcolony. London: University of California Press.

Mbembe, Achille. 2003. "Necropolitics." Public Culture 15 (1): 11-40.

Menninghaus, Winfried. 2003. Disgust: The Theory and History of a Strong Sensation. Translated by Howard Eiland, and Joel Golb. Albany: State University of New York.

Miller, Catherine. 2017. "Contemporary dārija Writings in Morocco: Ideology and Practices." In The Politics of Written Language in the Arab World: Writing Change, edited by Jacob Høigilt, and Gunvor Mejdell, 90-115. Leiden: Brill.

Mubasharatan Ma'akum. 2M. Casablanca. Television. November 29, 2013. https://www.youtube.com/ watch?v=7R7R0Wb40PI.

Newell, Stephanie. 2015. "Dirty Familiars: Colonial Encounters in African Cities." In Global Garbage: Urban Imaginaries of Waste, Excess, and Abandonment, edited by Christoph Lindner, and Miriam Meissner, 35-51. New York: Routledge.

Orlando, Valérie K. 2009. Francophone Voices of the New Morocco in Film and Print. Basingstoke: Palgrave Macmillan.

Sartre, Jean-Paul. 1988. What is Literature? and Other Essays, Introduced by Steven Ungar. Cambridge, Mass.: Harvard University Press.

Sater, James N. 2010. Morocco: Challenges to Tradition and Modernity. Abingdon and New York: Routledge.

Sokrat, Mohammed. 2014a. 'Modakkirat Sokrat f Sijn' (Sokrat's Prison Diaries), episode 13. February 10. https://www.goud.ma/2034/5703/.

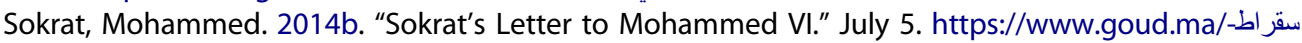
71139/. 711.

Sokrat, Mohammed. 2015a. "Sokrat Writes about Mohammed VI's 52 Birthday." August 20. https:// www.goud.ma/اليوم-166186/.

Sokrat, Mohammed. 2015b. "The PAM has Already Secured 700 Seats." August 28. https://www.goud. ma/167716/-البام -فالدخلة_عندو-700-مقعد-هاد-الانتخابـ/. 
Sokrat, Mohammed. 2015c. "This is where Chabat and Benkirane's Populism has Led Us." April 10.

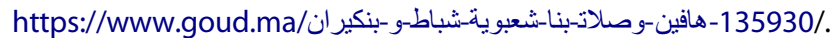

Sokrat, Mohammed. 2015d. "When they Wanted to Hire me in Le360 ..." October 3. https://www.

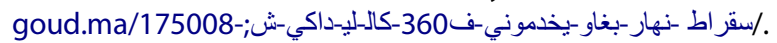

Sokrat, Mohammed. 2016a. "Enough of Crying over the Ruins, and Let's Save Le Desk." October 12. https://www.goud.ma/245700/.

Sokrat, Mohammed. 2016b. "It was the Arabization of Education that Ruined Us." December 13. https://www.goud.ma/257146/.

Sokrat, Mohammed. 2016c. "This is the Difference between the Goud School in Darija and Ayouch's

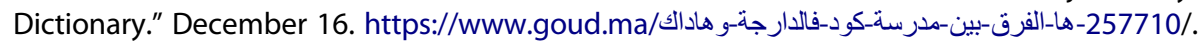

Spivak, Gyatri C. 1993. Outside in the Teaching Machine. New York: Routledge.

The New زحيليكر. 2014. https://www.facebook.com/pg/thenewz7iliker/about/?ref=page_internal.

Zaid, Hamid. 2017. Masharif. Presented by Yassine Adnan. Al-Oula Television. https://www.youtube. com/watch?v=0O5m4CNvLZ8. 